\title{
特集「水素の取り扱い方」企画の趣旨
}

\author{
犬 飼 潤 治 \\ 山梨大学燃料電池ナノ材料研究センター 函 400-0021 山梨県甲府市宮前町 6-43
}

(2015 年 8 月 7 日受付； 2015 年 9 月 20 日掲載決定)

\section{How to Treat Hydrogen}

Junji INUKAI

Fuel Cell Nanomaterials Center, University of Yamanashi, 6-43 Miyamae-cho, Kofu, Yamanashi 400-0021

(Received August 7, 2015 ; Accepted September 20, 2015)

\begin{abstract}
Storage, transport, and handling of hydrogen are now actively investigated. In this special issue, articles on the present status of hydrogen cylinders, metal and organic hydrides for hydrogen storage, and ammonium as a hydrogen carrier are presented by authors of two universities and three companies.
\end{abstract}

KEYWORDS : hydrogen, hydrogen cylinder, metal hydrides, organic hydrides, ammonia

\section{1. は じめに}

2011 年の東日本大震災と原子力発電所事故が, 日本 のエネルギー事情を一変させた。事故を踏まえて，2014 年には第四次の「エネルギー基本計画」が閣議決定され た ${ }^{1)}$ 。そこでは, 「水素は多様な一次エネルギー源から 様々な方法で製造でき, 気体, 液体, 固体というあらゆ る形態で貯蔵・輸送が可能であり, 利用方法次第では高 いエネルギー効率, 低い環境負荷, 非常時対応などの効 果が期待され, 将来の二次エネルギーの中心的役割を担 うことが期待される」と謳われた。水素を本格的に利活 用する「水素社会」の実現に向けた取り組みが, 国策と して宣言されたわけである。本基本計画の重要性につい ては, 本特集のそれぞれの解説でも述べられているとお りである。

水素利用に関連する産業も，国の方針に強く影響を受 ける。たとえば昨年 2014 年にはトヨ夕自動車株式会社 より燃料電池車が発表されたが，一般向けには水素ステ ーションの利用が可能な地域でのみ販売される。水素ス テーションについては, 国からの補助金交付を受けて 2015 年内に 100 か所が建設される計画となっており, 国のインフラ整備政策が汎用製品の販売と結びつくとい

E-mail : jinukai@yamanashi.ac.jp
う産業構造が生まれている。さらに, 巻頭言で述べられ ているように，水素の価格設定も大きな部分が国策によ ってきまる。また, 2020 年の東京オリンピック・パラ リンピックが水素社会実現の契機とされることも, 広報 されている。このようにして, 水素社会は, 経済的な帰 結ではなく未来に対する国家投資としての側面が大き い。

水素は製造され, 貯蔵・運搬され, そして使用され る。「表面科学」誌第 36 巻第 2 号の特集「水素の作り 方」は, 本特集と同様に日本表面科学会電極表面科学研 究部会の企画によるものであったが, 水素の作り方の科 学技術的な側面に興味を絞り, 政策に関する議論は意識 的に取り入れないようにした。一方, 本号の「水素の取 り扱い方」においては, バックグラウンドとして国策, 社会性, 経済性, 規制, 法律などの説明を, 自然な形で 行っていただくよう執筆者にお願いした。そのためもあ り,「水素の作り方」の執筆者は全員が官学の所属であ ったが, 本号「水素の取り扱い方」においては 5 件中 3 件の解説が企業からの寄稿である。

\section{2. 水素の取り扱い方}

水素の取り扱いで最もよく用いられるのは, 水素ボン ベである。研究室に納入される水素ボンべには, 一般に 約 $15 \mathrm{MPa}$ で水素が充填されている。一方, 燃料電池車 
に搭載される水素の充填圧力は $70 \mathrm{MPa}$ と，5倍近い圧 力となっている。この高圧で水素漏れや脆化を防ぎなが ら, ボンベの軽量化も行う必要がある。厳しい法的規制 と経済性をクリアしながら材料および製品開発を進める 必要がある。

水素吸蔵合金の研究は長く, 一部害用化もされてい る。超低温にする必要もなく, 圧力も低いので安全性も 高いというメリットがある。しかしながら，システム全 体の質量が大きくなることから沉用的な運用には至って いない。一方で容器自体を軽くすることが可能であるた め, 上手なシステム設計を行えば，高圧ボンべに置き換 わる可能性を秘めている。水素吸蔵合金中における広い 意味での水素の形態は, 表面科学にも重要な意味を持 つ。

ベンゼン, シクロへキサンなど，水素を可逆的に放出 する「有機ハイドライド」を用いた水素眝蔵と運搬は, 現在, 活発に研究されて実用化が進められている。この 「有機ハイドライド」を用いた水素䝪蔵システムは, 北 海道大学の市川勝名誉教授により提案, 開発されてお り, 日本発の技術である。常温, 常圧で睁蔵・運搬が可 能なことは何にも代えられない利点である。一方, 水素 の取り込みと放出には, 有効な触媒の開発が必須であ る。

水素キャリアとしてのアンモニアは，体積当たりに占 める水素の量が大きく水素の取り出しも比較的容易であ るという利点を持つ。完全に分解したときに水素と窒素 だけになるのも，環境適合性がいい。しかしながらアン モニア自体が毒性を有し，さらにアンモニア製造のため のハーバー・ボッシュ法は高温・高圧で行われるため, エネルギー的に有利ではない。乗り越えるべき壁も高い
が，魅力的な技術である。

今回の特集では, これら水素の取り扱いを研究する産 学の研究者より解説記事をいただいた。筆者の多くは表 面科学の専門家ではなく, また執筆内容自体も表面科学 と直結したものとは必ずしもいえない。しかしながら， そこには材料開発や反応過程解析などを通じ, 表面科学 の活躍するべき場が存在することを, 会員読者は読み取 っていただけることと思う。

\section{3. を め}

政策についての記述が多かった最近の特集は，「表面 科学」誌 第 36 巻 第 6 号「表面科学新世代を築く次世 代放射光源」かもしれない。放射光施設の利用は宇宙開 発と並んだビッグサイエンスであり, 科学の最先端を目 指しながらも国策と無縁ではいられない。同様に，環 境・エネルギー科学も国の政策に大きな影響を受ける。

このような分野に打ける研究には，ひょっとしたら青 空の感じられない，あるい意味での圧力を感じる面もあ るかもしれないが，一方で，与えられたフィールドを有 効に活用する面白さもあるであろう。また，フィールド が限られているゆえに，科学的にみても尖った面白さが 現れることもあり得る。

本特集の解説は, 「表面科学」誌の記事としては変わ った内容であるが，執筆者の皆様の努力で読みやすい記 事がそろっている。のんびりとページをめくりながらい ろいろな考えが浮かぶような特集となっていると思う。

\section{文献}

1) http://www.enecho.meti.go.jp/category/others/basic plan/pdf/140411.pdf 